\title{
EEN WOORD OVER DEN WATERSTAAT IN NOORDBRABANT.
}

\author{
Aan de Economist.
}

Voor het geval de redactio meent, dat het nuttig kan zijn, eone opvatting van de zaak te kennen, die wellicht verschilt van de tot nu toe bestaande meeningen, deel ik hier de mijno zeer in 't kort mede.

Er zijn bij de watervrijmaking van 't noordoosteljjk deel van Noordbrabant twee zeer onderscheidene belangen in het spel: die der opgezelenen, en die der groudeigenaren.

Onder opgezetenen en grondeigenaren moeten niet alléén verstaan worden de bewoners en bezitters van de door dijkbreuk, of Beersch, of overlaten benadeelde streken, maar in tamelijk wijden kring, die streken, waar afwatering belet wordt door den hoogen waterstand in de lagere gedeelten. Het nieuw gevormde "Groot Waterschap" etc. geeft eenigzins den kring aan, die echter gerustelijk nog grooter gemaakt kan worden.

De opgezetenen nu (in dien grooten kring) hebben belang bij het wegblijven van het hooge water in den winler en in den zomer.

De grondeigenaren evenwel hebben voor bijna het totaal allén belang bij het uitblijven van het hooge water in den zomer. Dat benadeelt in den zomer alle oogsten, en vernietigt de opbrengsten. In den winter is onderstaan der landerijen wenschelijk, en onverschillig of zij 1 of 3 meters diep onderstaan.

De werken te vorrichten tot het voorkomen van zomerwatervloed, komen dus in hoofdzaak ten bate der grondeigenaren. Ze zouden werken tot landverbetering genoemd kunuen worden.

Daartoe helben de grondeigenaren dus krachtig bij te dragen. Misschien meer dan nu aangeboden is, en wellicht zonder al die beperkende voorwaarden, die alléén bewijzen dat de historie ten deze wantrouwen heeft gewekt.

De opgezetenen kunnen niet gevraagd worden tot bijdragen in de kosten. $Z_{i j}$ hebben zich voortdurend tegen de watervloeden gedekt door verplaatsing van bedrijf on verhooging der wo. ningen. De watervloeden komen echter telkens hooger, en sinds 
eenige jaren ook des zomers. Eendeels wordt dit veroorzaakt door den aanleg van wegen en spoorwegen in het overstroomende deel. Overal wordt wat water tegengehouden; overal worden bruggen en doorlaten op minimum vermogen geconstrueerd. Maar bovenal is de oorzaak van de zomervloeden en steeds hooger komende wintervloeden: het normaliseren van den Rijn en de Maas in de bovenstroomsch liggende rijken; misschien ook wel het aanbrengen der zeer talrijke kribwerken benedenwaarts; alzoo veel vermeerderde toevoer van boven, eenigsints verminderde afvoer beneden, en sterk belette doorstrooming op het terrein zelf.

Deze oorzaken wijzen zonder tegenspraak op Staatshulp.

De discussien in onze Volksvertegenwoordiging, vooral in de Eerste Kamer, bedoelden voornamelijk in het licht te stellen dat de dijken hier onvoldoende zijn, en dat eerst verbetering daarin gebracht moest worden, eer men klagen mocht, en sluiting bijv. der overlaten vragen.

De dijken behoeven hier en daar herstel, en ook ik ben niet vreemd aan de gedachte dat de zoo ruime en niet altijd oordeelkundige watersnood-mildheid, onze dijken wel wat heeft doen verwaarlozen. Maar daartegenover staat: eerstens, dat bijv. dit jaar watersnood was en op de geïncrimineerde plaats geen doorbraak. Troeedens, - dat 't land van Heusden en Altena dit jaar achter zijne zware uitstekende dijken toch niet reilig bleek. Derdens: - dat de Bommelerwaard dezer dagen ook rekwestreerde om 't uitvoeren van den nieuwen Maasmond te verkrijgen, overtuigd dat de sterkste en hoogste dijken onvoldoende moeten worden tegen de steeds hooger komende vloeden.

De Tielerwaard, die nu zoo stout spreekt, kan ieder jaar de les krijgen, die Heusden en Altena dit jaar ontvangen hebben.

$\mathrm{Nu}$ is er een basis voor' $\mathrm{t}$ geen de grondbezitters zouden moeten betalen. $\mathrm{Er}$ bestaan namelijk plans en begrootingen voor waterwerken, die de landen in kwestie van zomerwater zouden bevrijden. Het leeuwendeel dier kosten zouden de grondeigenaren moeten betalen. Maar die plans en meer andere zaken die hierbij onontbeerlijk zijn, zijn mij niet genoeg bekend om eenige cijfers te kunnen geven. Dit weet ik, dat men dezerzijds sterk opziet tegen het geven van veel geld, altijd hopende dat de regeering het toch wel doen zal!

Minder bij de zaak behoorende, maar toch curieus is de oplossing eener vraag, die ik mij sedert jaren reeds stelde, maar toch eerst onlangs kon oplossen; namelijk, hoe 't mogelijk was 
dat een dergelijke rampzalige toestand zoo lang heeft kunnen bestaan; want was het nooit zoo erg als thans, het was toch erg genoeg.

Die oplossing is, naar ik meen, deze:

De watervloeden kwamen weinig in den zomer. De oogsten waren overvloedig en de pachters konden betalen. De grondeigenaar werd dus eerst benadeeld toen de zomervloeden begonnen te komen en het verpachten der landerijen onmogelijk werd. En ook sinds die zomervloeden zijn de groote klachten over den ellendigen toestand ontstaan.

De vorige toestand, wintervloeden, die laat in het voorjaar bleven, waren den grooten grondeigenaar zeer welkom, als een middel om zijn grondbezit goedkoop te vermeerderen.

De kleine grondeigenaar, pachter tevens, kon na eenige achtereeuvolgende jaren tegenspoed, nooit zijne pacht betalen, en kwam zoo langs den weg van hypotheek tot verkoop van zijn klein bezit. Die verkoop ging uit nood en in slechte jaren, dikwijls uit schaamte onder beding van voortdurende huur, dus tegen lagen prijs - en de groote grondeigenaar werd grooter.

Zonder dat het dus ooit uitgesproken werd, bestond er tusschen de grootere grondeigenaren een Secpet de la comédie en gingen or geen klachten op.

Dit is de eenige verklaring van het anders onbegrijpelijke feit, dat hier nooit serieus werk van de zaak gemaakt werd, en van het feit, dat er nu wel werk van gemaakt wordt, maar zonder eenige geestdrift.

Dringend noodig acht ik het, dat de belangen der opgezetenen eens warm bepleit worden, en dat eindelijk eens een einde kome aan onzen inderdaad ongehoorden toestand. De boerenstand verarmt; de middenstand verdwijnt. De moed zakt; men wordt onverschillig en de ellendigste toestand wordt nog verergerd door de demoralisatie ten gevolge der groote liefdadigheid.

Misschien kan het nuttig zijn, dat velen deze beschouwing van den stand der zaken eens rernemen.

Hoogachtend teeken ik

Uw dw. dienaar, EEN OPGEZETENE. 